\title{
Seventeenth and eighteenth century timber roof structures in Scotland: design, pathologies and conservation
}

\author{
A. Serafini \& C. Gonzalez Longo \\ Department of Architecture, University of Strathclyde, Glasgow, UK
}

\begin{abstract}
Seventeenth and eighteenth century architecture in Scotland has not been sufficiently researched, despite its importance in both quality and quantity. Most scholars tend to investigate the external architectural composition of these buildings rather than their overall constructional configuration. In particular, timber roof structures are very rarely considered even though the integrity of the overall building depends largely on them. This lack of knowledge hinders good conservation practice. This paper aims to increase awareness about the extent, nature, value and condition of historic timber roofs in Scotland in order to understand what their conservation needs are. Preliminary results obtained from the creation of a relational database of 1550 buildings, related mapping, survey of 56 buildings of the period across Scotland and histori$\mathrm{cal} /$ archival research, are discussed. This has allowed for an initial understanding of the different structural types of Scottish timber roofs of the period as well as their pathologies.
\end{abstract}

\section{INTRODUCTION}

This work is part of a wider research on seventeenth and eighteenth century architecture in Scotland being carried out by the Architectural Design and Conservation Research Unit (ADCRU), in the Architecture Department of the University of Strathclyde. The aim is to recognize the value of this important built heritage, which has not been sufficiently investigated so far, in an integrated and comprehensive way, beyond the usual external descriptions.

A relational database of 1550 buildings from the period has been created. It includes information on structures, designers, craftsmen, clients and the different interventions. During this research it became apparent that timber roof structures are one of the most neglected topics of research and as consequence their value is not appreciated and many of the original roofs are replaced. Research on the use of timber in Scottish architecture has been widely published but there has been little focus on its structural use, particularly in roofs. Despite the recent work of scholars such as Hanke (2006), Newland (2010), and Crone (Crone and Mills 2012), we are still unable to say what is the extent and nature of original Scottish timber roofs, even because the research done is based more on archival documents and literature than on surveys. Moreover, no research has been carried out on the present condition of these structures. This lack of knowledge hinders good conservation practice: the value of Scottish timber roof structures is not recognized and their structural behaviour is often misunderstood, resulting in their replacement or over-consolidation.

The assessment of historic timber structures can be challenging, being timber an organic material with variable properties. Professionals are often uncertain about the safety of a timber roof structure, due to the lack of training and knowledge on timber structural behaviour, the limited amount of regulations for historic timber structures and the difficulty to determine in situ the timber species and properties. The available testing and modeling methods require a lot of experience and can be expensive and labour intensive. As consequence, the original timber structure is often replaced or over-consolidated with what is considered a "safer" material (steel or concrete).

This paper aims to increase awareness about the extent, value and nature of seventeenth and eighteenth century timber roofs in Scotland and to understand what their conservation needs are. An initial survey and assessment of 56 buildings across Scotland has allowed identifying different roof structural types, their design, development and their pathologies and possible causes.

Future work will comprise an in-situ testing campaign to further investigate the critical areas identified and to address specific issues and limitations that professionals might encounter during the assessment of these structures. The aim is to develop a method for the initial assessment of timber roofs that can contribute in improving local practice. 


\section{METHOD}

\subsection{A database of seventeenth and eighteenth century buildings in Scotland}

In order to assess the extent, nature and condition of seventeenth and eighteenth century Scottish timber roofs, the first step was to identify Scottish buildings of the period. A database and related mapping has been developed with Microsoft Access and ArcGIS: this tool has been used to locate the buildings and record their history, based on data from the databases of Historic Scotland - now Historic Environment Scotland - (HS 2015), the Royal Commission on Ancient and Historical Monuments of Scotland (RCAHMS 2015) and the Buildings at Risk Register (BARR 2015), as well as literature on Scottish Architecture (Glendinning \& Mackechnie 2004). The results from the surveys and archival/historical research are being added to the database as the research progresses; it now includes 1550 buildings.

\subsection{Selection of key buildings}

The database has been used to select key buildings to survey, according to the following criteria:

- designed by architects and of a certain scale;

- no flat roofs;

- major interventions in seventeenth and eighteenth century and no major alterations after 1800;

- key moments in Scottish architectural history;

- roof or wrights' names mentioned in literature or in HS/RCAHMS/BARR;

- original plaster ceilings;

- analysed with dendrochronology;

- owned by HS or NTS (for accessibility);

- in the Scottish central belt (for accessibility);

- designed by Sir W. Bruce, J. Smith or W. Adam, leading architects of the period (Serafini \& Gonzalez-Longo 2015, Gonzalez-Longo, 2012, Gonzalez-Longo \& Theodossopoulos, 2012).

The owners of 139 buildings have been contacted and 80 of them replied: 66 granted access and 8

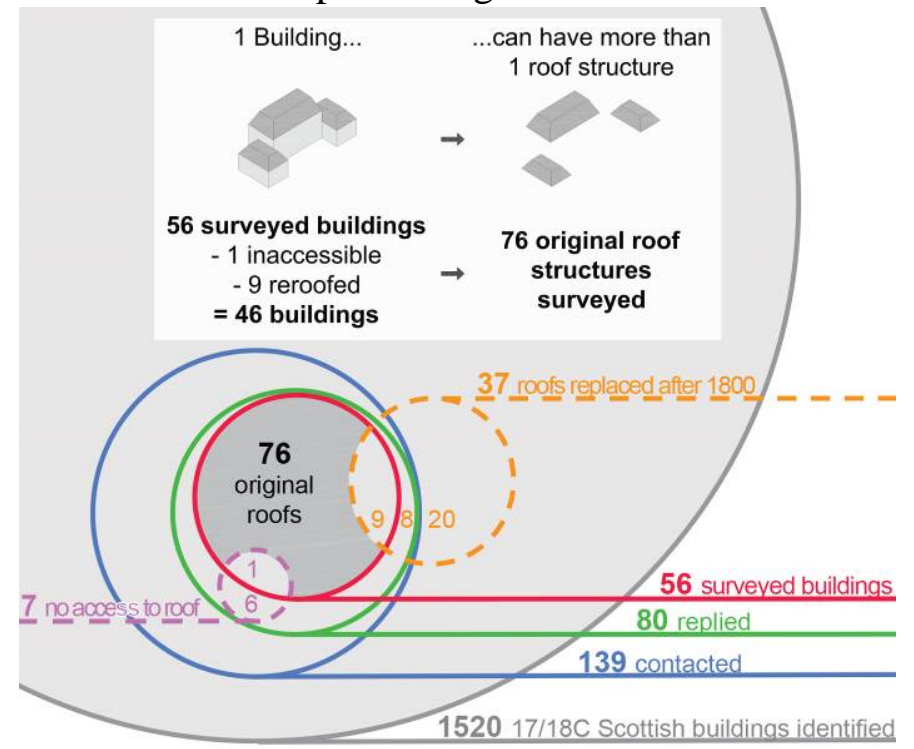

Figure 1. The key buildings' selection process informed of the replacement of the roof after 1800 (Fig. 1). Visits to 56 buildings (or groups of buildings, as in Fort George) were eventually arranged (Fig. 2). Of these buildings one had no accessibility to the roof structure and 9 had roofs replaced after 1800. The other 46 buildings/groups of buildings had one or more original roof structures for a total of 76. A building has been considered as having more than one roof structure when these are structurally independent, separated by masonry walls. Thanks to literature references 20 other buildings have been identified as having the roof structure completely replaced after 1800, for a total of 37 (Fig. 1).

\subsection{Surveys}

The objective of the surveys was to gain first-hand knowledge on the roofs' construction techniques and typologies and to start assessing their present condition. As suggested in guidelines for the assessment of historic timber structures (Cruz et al 2015), a desk survey was carried out prior to the visits to gather all the necessary information on the buildings, then a preliminary visual and measured survey was done. A tape meter, a laser meter and a digital camera were used. A series of fixed parameters have been recorded during the surveys in order to compare the structures and draw some conclusions from a historical, typological, technological and structural point of view. The parameters recorded include:

- roof form (gabled, hipped, dome, etc);

- roof geometry (span, pitch, length, etc);

- structural arrangements (common rafter roof, purlin roof, etc, as well as the type of frame/truss);

- connection with walls;

- elements' scantlings and section shape;

- timber dressing (hand-axed, hand-sawn, etc);

- joint types and fasteners;

- timber species (if known);

- roofing material and its fasteners;

- carpentry marks;

- evidence for reused timber.

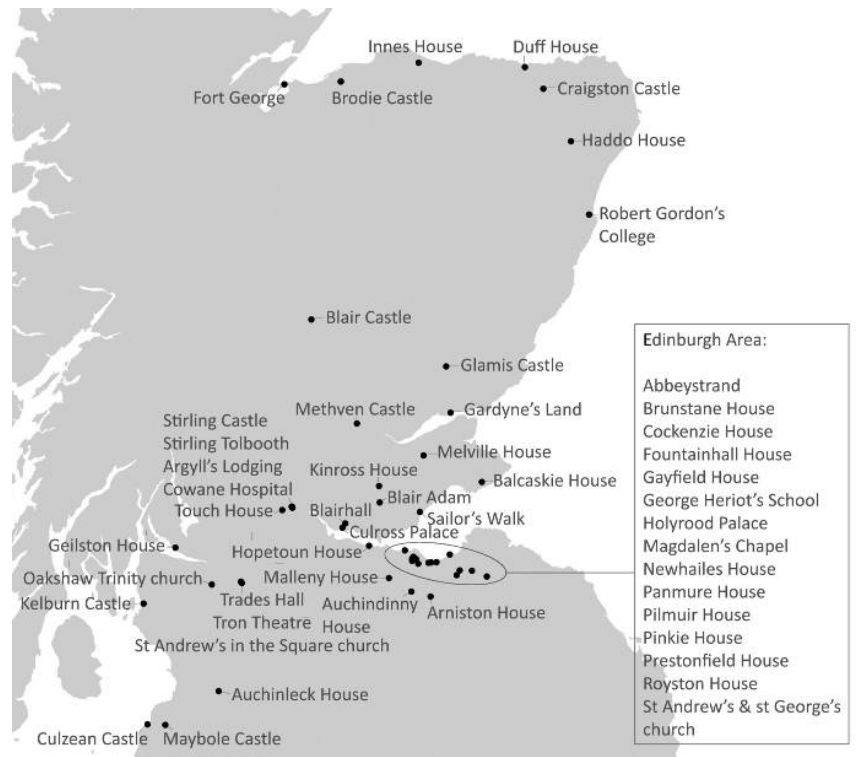

Figure 2. The 56 buildings surveyed across Scotland 
Signs of damage have been recorded as follows:

- mechanical damage (deformations, cracks, etc);

- material degradation (fungi/insect attack, etc);

- past interventions;

- unfavorable environmental conditions (poor ventilation, etc) and poor maintenance;

Natural defects (knots, checks, etc) have not been documented at this stage. All the information has been collected in a structured form integrated within the database. The form has been produced in collaboration with COST Action fp1101 and further developed to meet the purposes of this research.

The surveys have helped identifying different structural types and their pathologies, as well as issues in their assessment.

\subsection{Archival Research}

Archives have been searched for information on the surveyed buildings and on wrights of the period. The research has focused on archives in Glasgow and in Edinburgh. The documents consulted include mainly accounts and correspondence that have been used to understand the design and construction processes, the timber procurement, past repair works, the people involved and, in particular, the role of architects and wrights. The study of carpentry manuals of the time (Gomez Sanchez 2006) has helped understanding what knowledge the wrights had access to and if there has been migration of technical knowledge.

\section{THE IDENTIFICATION OF STRUCTURAL TYPES AND THEIR DEVELOPMENT}

The development of timber roofs' design and construction is closely related to material availability and to the development of the architecture of the period: its layouts, spans and overall composition. The challenge in Scotland at the time was to pass from large spans covered by open purlin structures such as the fifteenth century Darnaway Castle (Stell \& Baillie 1993), to large spans covered by shallower roofs carrying heavy plaster ceilings, fashionable from seventeenth century (Fig. 3). Whilst the few remaining Scottish open purlin roofs have been widely investigated, little research has been done on roof structures hidden behind timber and plaster ceilings, which, according to our surveys, cover the vast majority of Scottish buildings throughout the centuries. Hanke (2006) is the only scholar who has previously investigated these roof structures, but he considered mostly documents related to buildings up to 1647 in a restricted geographical area. Newland (2010), Thomson (1991), Crone and Mills (2012) have researched the timber trade of the period.

\subsection{Common rafter roofs}

Before 1500, local Scottish timber was used; oak was considered to be the most valuable, due to its strength and resistance, and used whenever possible for the construction of high status buildings (Newland 2010). From the few remaining roof structures of the period, one can deduce that single pile buildings were covered with gabled roofs whose internal structure was an open purlin roof in case of big spans, and a stone vault in case of reduced spans (Fig. 3). It is not clear when common rafter roofs started being employed. The oldest surviving one could be that of Alloa Tower, first mentioned in 1497 (Ruddock 1995).

In sixteenth century double piles were introduced and common rafter roofs were used with the intermediate spine wall acting as additional support (as in Drochil Castle, Fig. 3). In this period it was hard to find local timber suitable for building construction, due to accessibility problems and low quality: thus oak and pine started being imported from the eastern Baltic, Denmark, Sweden, and Norway soon dominated the market (Newland 2010).

The sixteenth and seventeenth century common rafter roofs we have surveyed (see for example Culross Palace, Fig. 4) are generally simple, composed of rafter couples, spaced $30 / 60 \mathrm{~cm}$, with one or two collar beams, almost square scantlings of $10 / 15 \mathrm{~cm}$, and mortise and tenon or simple lap joints secured with timber pegs. The spans are usually less than $7 \mathrm{~m}$, and the pitches are quite steep $\left(50^{\circ}-60^{\circ}\right)$.

The extensive use in Scotland of very simple common rafter roofs throughout the centuries up to today (Fig. 3) is somehow unusual, considering that in England and Northwest Europe structures started changing already in 13C, when king/queen struts and side purlins were introduced (Hanke 2006). Moreover, Scottish common rafter roofs have some characteristics quite different from the English and European ones, as confirmed by our surveys: they have no tie-beam up to 1700 ; they never have additional longitudinal bracing other than the sarking (longitudinal timber boards fixed to the rafters and supporting the roof covering); they have no wallplates up to late seventeenth century but sometimes provide additional rigidity through the rafter foot, with the ashlar piece extended downward on the masonry.

As Hanke (2006) suggests, the simplicity and uniformity of Scottish common rafter roofs could be explained by the reliance on imported timber, which seems to have favoured timber structures characterized by few standardised items: deals (timber boards for the sarking) and straight, relatively short beams. According to our surveys, this could be true only up to 1670 s, when structures start evolving (Fig. 3).

\subsection{End 17C and 18C: more complex frames}

From 1670s onwards common rafter roofs had to adapt to the new geometries of classical architecture, introduced in Scotland by the architects Sir William Bruce and Mr James Smith. M roofs, hipped and 


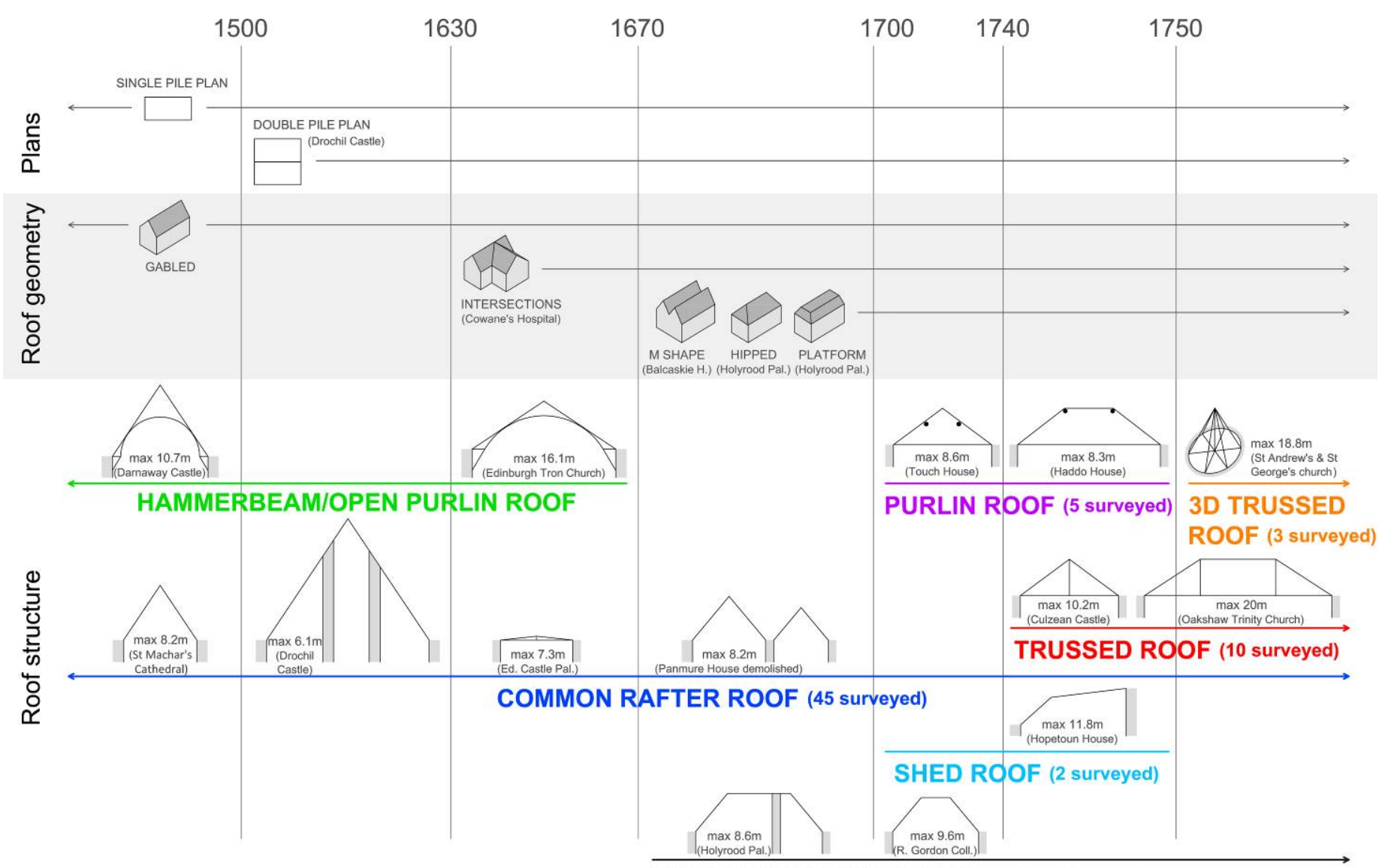

MORE COMPLEX FRAMES: platform frames, frames with primary \& secondary rafters, frames with tension absorbing members (13 surveyed)

Figure 3. Construction development of Scottish timber roof geometries and structures

platform roofs were introduced (Fig. 3). Wall-plates started being used, as well as tie-beams and tension absorbing joints (dovetail) and members, which shows an understanding of the fact that timber elements can behave in tension too. The internal structure of platform roofs were solved in a quite particular way, as in Melville House (Fig. 4).

Later in eighteenth century the spans increased (up to $9.86 \mathrm{~m}$ in Duff House 1735), and the pitches became shallower (down to $23^{\circ}$ in Yester House 1729, Fig. 4), forcing the internal structures to become more efficient: the elements' sections became more rectangular and butt-purlins were introduced. Rafters started being distinguished into primary and secondary ones, which significantly reduced the amount of timber needed. In Yester House (1729, Fig. 4), for example, primary frames are connected by purlins, which in turn support the common rafters. This arrangement is quite different from those of Culross Palace and Melville House (Fig. 4), where all the rafters and frames are the same, with no distinction between primary and secondary. The 'more complex frames', such as the one at Yester House, seem to have a structural behaviour in-between common rafter roofs and trusses, and could be antecedents of the latter (Serafini \& Gonzalez Longo 2015).

\subsection{Purlin roofs}

In eighteenth Norway declined as supplier of timber due to the over-exploitation of its natural resources; its role was taken first by Sweden and then by the eastern Baltic area, exporting balks, to be sawn to meet individual needs, and deals of pine (Thomson 1991). In this period home-grown pine was used as well (Crone \& Mills 2012). In the second half of eighteenth century timber was also imported from the Americas, as was happening in England (Yeomans 1992): the West Indies sent exotic hardwoods such as mahogany and American Colonies and Canada provided oak and walnut (Thomson 1991).

The change in the timber trade mirrors changes in construction. Purlin roofs started being employed from late seventeenth century (Fig. 3): Melville House (1697/1703) is the earliest purlin roof we've surveyed (Fig. 4). Unfortunately, the limited number of surveyed examples makes it difficult to draw conclusions on their development. Nevertheless, it is interesting to note that purlin roofs were often coupled with other structural types in the same building, with no apparent reason driving the choice of one structure or the other. This could suggest that either the different timber structures have been constructed in different periods, or, if they appear to belong to the same period (as is the case of Melville House, Fig. 4), that wrights/architects were experimenting.

\subsection{Trusses}

Our surveys suggest that from 1740s/50s king-post trusses started being used to cover reduced spans (Fig. 3), and princess-post trusses and queen-post 


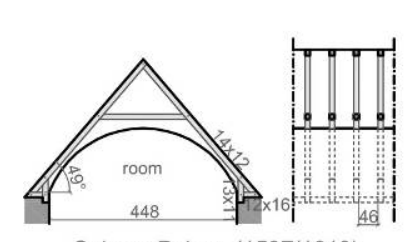

Culross Palace $(1597 / 1610)$

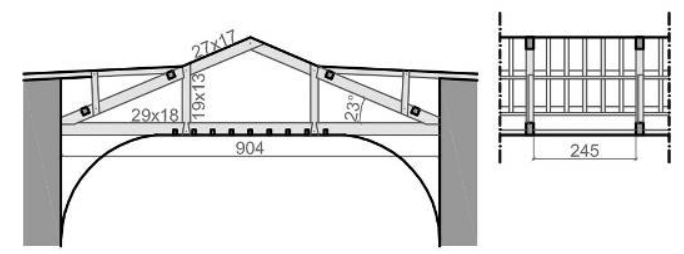

Yester House (1729)

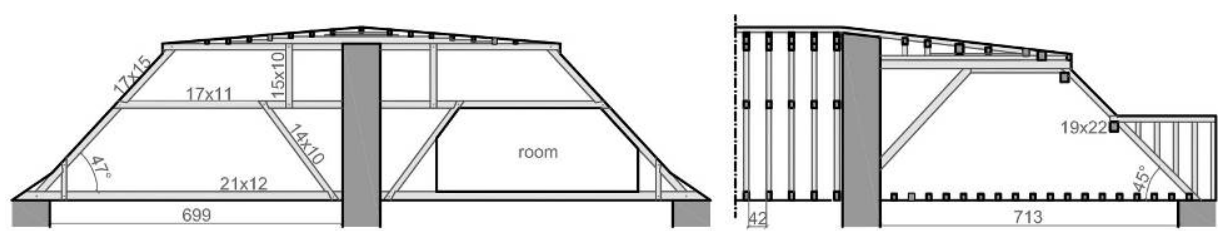

Melville House (1697/1703)

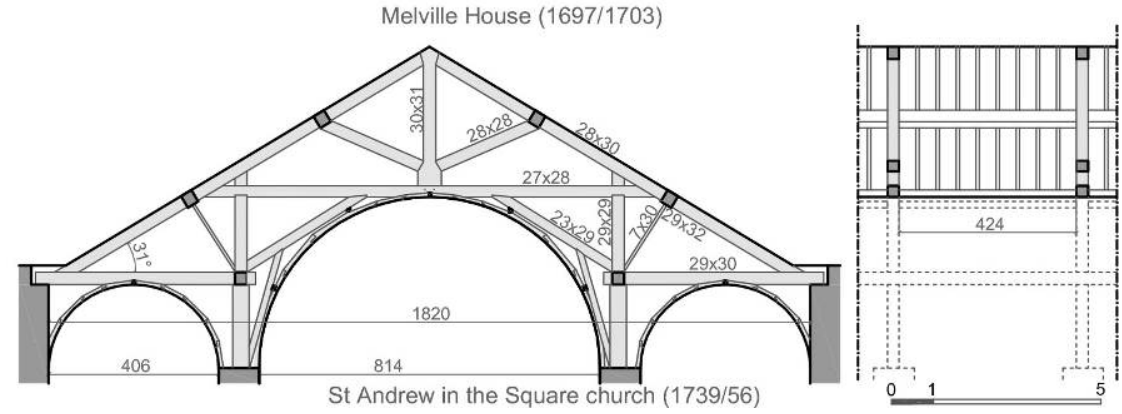

Figure 4. Top left: common rafter roof in Culross Palace (1597/1610); top right: platform frame and purlin roof in Melville House (1697/1703); bottom left: more complex frame in Yester House (1729); bottom right: princess post truss in St Andrew in the Square church (1739/56).

trusses to cover bigger spans (as in St Andrew's in the Square church 1739/56 - Fig. 4). Spans reach their maximum in Oakshaw Trinity church (1754/6) with $20 \mathrm{~m}$, and pitches vary between $44^{\circ}$ and $27^{\circ}$. The sarking is retained, even though butt-purlins are always used. Joints are all mortice and tenon with no fasteners or timber dowels; scarf joints are very rare. Metal straps are seldom used as well - they are often a later addition. Posts normally have joggles, which could be an English influence (Yeomans 1992), but traces of other influences can be identified too (Serafini \& Gonzalez Longo 2015).

It is still not clear how the truss was introduced in Scotland. The arrangements and construction details of the earliest Scottish trusses show little understanding of their structural behaviour. The truss in St Andrew in the Square church (Fig.4), for example, shows an improper design of the joint between the post and the raised tie-beam: it's a simple mortice and tenon joint with no fasteners, which cannot work in tension and counteract the tie-beam deflection. An analysis of drawings and buildings of the Adam architects suggests that although they aspired to build trusses, wrights were initially unable or unwilling to construct them. An external influence was probably necessary for the introduction of trusses in Scotland (Serafini \& Gonzalez Longo 2015).

\section{PATHOLOGIES AND POSSIBLE CAUSES}

\subsection{Assessment of historic timber structures}

The assessment of timber structures can be challenging because of the organic nature of the material and its variable properties.

Recent research has outlined a methodology for the on-site assessment of historic timber structures (Feio \& Machado, in press, Cruz et al 2015). They suggest a preliminary assessment based on a desk survey followed by an on-site visual and measured survey, where moisture content readings and Visual Strength
Grading (VSG) are carried out. Resistance Microdrilling can be used to assess invisible decay and structural analysis can identify highly stressed areas. The information gathered can then be used in a final structural analysis to verify if the structure complies with the ultimate state requirements. If it fails, a more detailed survey (using other nondestructive/semi-destructive tests - NDT/SDT) must be carried out and the structural analysis updated.

VSG is a powerful method but it has limitations: the subjectivity and low experience of the inspector, limited accessibility, non-visible internal decay, and lack of specific criteria in most national standards. It also requires the timber species identification, which is often not doable (Macchioni 2010). Alternatively, mechanical properties can be estimated with SDT (Kloiber et al, in press) or stress waves methods. Unfortunately, NDT and SDT also have many drawbacks: poor correlation with material properties; the information obtained is often qualitative/local; the test procedure and the results' interpretation require a lot of experience; it is not clear how to use the collected data; some devices are not on the market yet. This is why most professionals don't use NDT/SDT but rely mainly on experience, even though this can lead to underestimating the structure's condition and replacing or over strengthening the whole roof.

\subsection{Typical damage in Scottish timber roofs and possible causes}

As explained in section 2, it is known that 17 buildings out of $80(\sim 20 \%)$ have been reroofed after 1800 (mainly in 20C), because thought to be structurally unsafe. $20 \%$ is quite a high percentage and suggests either a conservative approach on the professionals' side, leading to the replacement of structures even when not necessary, or poor maintenance on the owners' side, leading to damage/degradation beyond repair. In both cases it is clear that the value of these structures is not recognized and that good conserva- 
tion practice is hindered by lack of information, training and method. In order to overcome these limitations, a preliminary visual inspection was carried out to start identifying the typical pathologies and possible causes of the different structural types.

\subsubsection{Poor initial design}

Poor initial design (overall structural arrangement, joints, timber dressing) seems to play a key role in causing damage in all of the roofs surveyed, which is not unusual (Tampone 2007).

Common rafter roofs show joint disconnections/splitting that can be associated with an overall transversal opening of the roof. As already stated, up to about 1670 simple lap or mortise and tenon joints are used, secured with timber pegs. These joints are not capable of resisting tension forces, which the lower collars and rafter feet are subject to. The timber pegs fail easily (also because of biotic attack) and the joints start opening (Fig. 5 left). Even in later roofs, dovetail joints can fail if the timber cracks and splits around the metal nail (Fig. 5 center).

Other common rafter roofs have a problem in the longitudinal direction, with the frames stacking up and losing stability (Fig. 5 right). This seems to happen when the distance between the frames is more than the common $50 \mathrm{~cm}$, because the longitudinal rigidity is provided only by the sarking boards.

Trusses with spans below $10 \mathrm{~m}$ are generally in good conditions, whilst those covering bigger spans sometimes have deflections in rafters and tie-beams, joint disconnections and cracks (Fig. 6), which suggest an
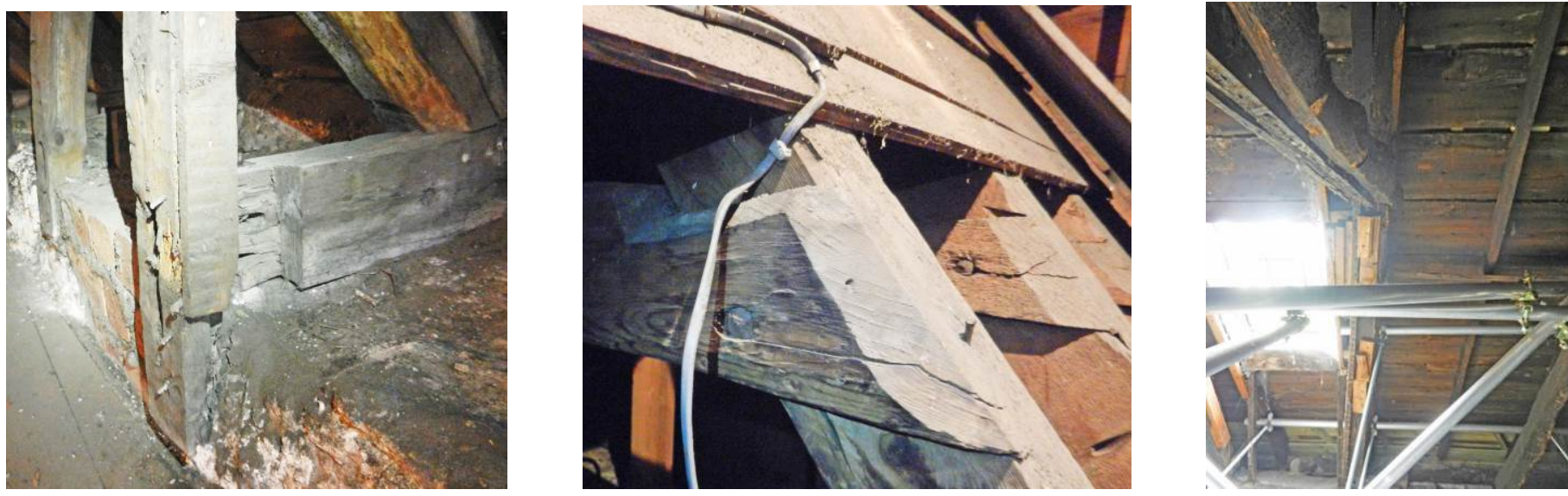

Figure 5. Mechanical damage in common rafter roofs. From left to right: joint disconnection in Sailor’s Walk (Kirkcaldy, Fife), joint splitting in Touch House (St Ninians, Stirling), stacking up in Geilston House (Cardross, Argyll and Bute).
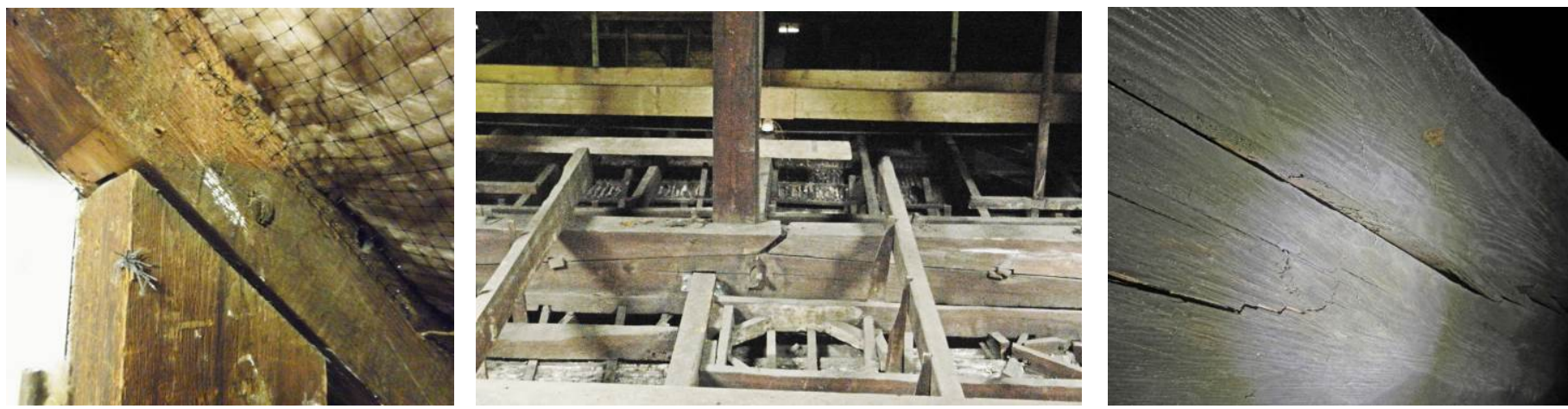

Figure 6. Mechanical damage in Trussed roofs. From left to right: joint disconnection in Fort George Ordnance Store (Ardersier, Highland), joint disconnection in Oakshaw Trinity Church (Paisley, Renfrewshire), crack in rafter in Glasgow Trades Hall.
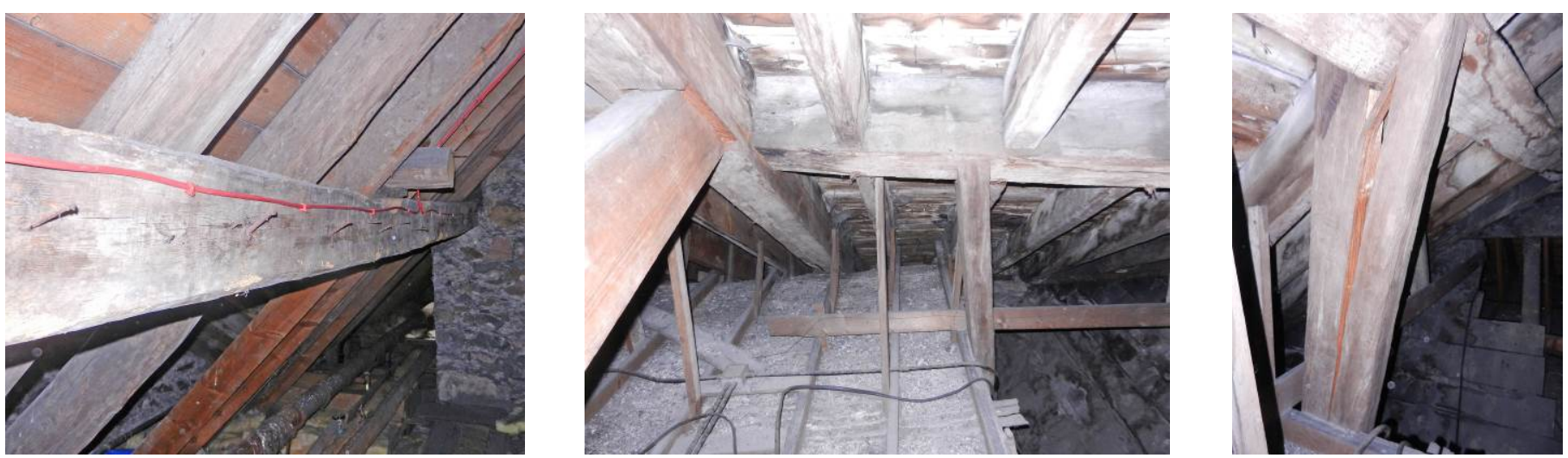

Figure 7. Mechanical damage in purlin roofs. From left to right: deflected purlin in Melville House (Monimail, Fife), deflected purlin in Touch House (St Ninians, Stirling), crack in strut in Touch House (St Ninians, Stirling). 
overall deflection and opening of the roof structure. One of the causes is the improper design of arrangements and joints: timber elements are often too long and do not have sufficient propping provided; joints are almost exclusively mortise and tenon secured by timber dowels or nothing, which work only in compression (Fig. 6, left); metals straps are very seldom used and sometimes they are a later addition; scarf joints, when used, are very simple (Fig. 6 center), and again unable to absorb tension forces.

Purlin roofs often have deflected purlins and cracked struts (Fig. 7), caused by insufficient dimensions or lack of supports.

Common rafter roofs also have material degradation problems (fungi, insects, etc), that might be caused, amongst other, by the rough dressing of the timber elements, which often retain some bark and sapwood, more subject to biotic attack (Ridout 1999). Trusses and purlin roofs seem to be less vulnerable, probably because the timber for these bigger and more complex structures was carefully selected to be of high quality, and carefully squared and finished.

\subsubsection{Past interventions}

Past alterations and repairs contributed in creating/accelerating damage in some cases.

Gardyne's Land (end seventeenth century), for example, has deflected collars in the central part of the roof, where a pediment was added in early 18C (Fig. 8 left). Another example is Oakshaw Trinity church, where the heavy plaster ceiling was probably added/replaced in nineteenth century, causing deflections and joint disconnections due to the additional dead load (Fig. 6 center).

There is often no documentation on past repairs and why they have been done. Temporary interventions often become permanent, and their effect on the structure is not monitored. Whilst in eighteenth and nineteenth century timber was used to either replace the whole roof or double its structure (Fig. 8 center), in the twentieth and twenty-first century steel became more fashionable. The weight of steel is often a problem for the masonry and the plaster ceilings. For example, timber posts and steel beams were added in Oakshaw Trinity church to support the hip rafters that were deflecting (Fig. 8 right); this inter-
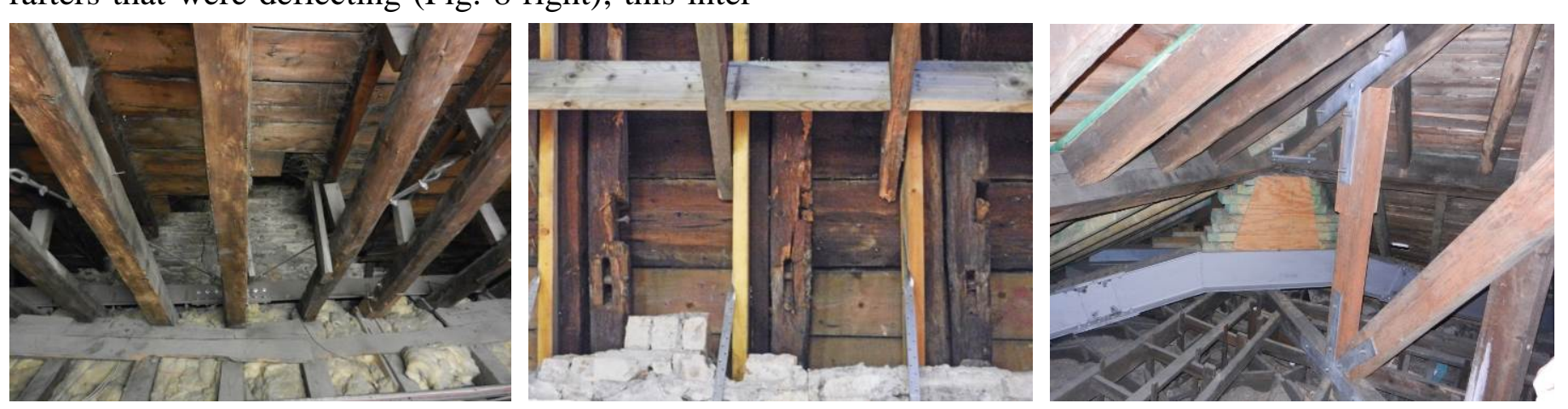

Figure 8. Past interventions. From left to right: Steel beam and ties counteracting the collars' deflection in Gardyne's Land (Dundee), 18C and 21C timbers strengthening the original 17C timbers in Panmure House (Edinburgh), timber posts/struts and steel beams/straps counteracting the hip rafters' deflection in Oakshaw Trinity church (Paisley). 


\section{CONCLUSIONS}

Seventeenth and eighteenth century Scottish built heritage has not been sufficiently researched. In particular, very little is known about timber roof structures, which are very seldom inspected. This lack of information hinders good conservation practice: the roofs' value is not recognized and their structural behaviour is often misunderstood, resulting in their replacement or over-consolidation.

A relational database and mapping of seventeenth and eighteenth century Scottish buildings has been developed and used to select 56 key buildings to survey. A preliminary assessment based on historical/archival research and visual/measured on-site survey has been carried out. This has allowed identifying different structural types, their design and development, pathologies and possible causes, and issues in their assessment.

Research so far has focused on few medieval open purlin roofs. However, our surveys suggest that the vast majority of Scottish roofs throughout the centuries were common rafter roofs, purlin roofs and trusses, hidden behind timber/plaster ceilings. The apparent simplicity and uniformity of Scottish common rafter roofs could be explained by the reliance on imported timber from Norway, but this could be true only up to 1670 s when common rafter roofs evolve and adapt to the new geometries of classical architecture. In eighteenth century wrights and architects start experimenting with purlin roofs and trusses. Considering the limited number of surveyed purlin roofs, it seems that their use remains restricted. Trusses are instead employed from 1740s in the vast majority of public buildings and big country houses, and they are soon used even for reduced spans. However, their arrangements and construction details suggest that their structural behavior was not always understood.

No research has been previously carried out on the present condition of Scottish timber roofs. Our surveys have highlighted how all of the structural types show damage that seems to be caused mainly by poor initial design, but also by past alterations and repairs, poor environmental conditions and poor maintenance. Common rafter roofs seem to suffer of material degradation more than others. In order to assess hidden parts of the structure and verify the hypothesized causes of damage, future work will comprise an in-situ testing campaign, with the aim to contribute in improving local practice.

\section{ACKNOWLEDGMENTS}

This research is being funded by the University of Strathclyde and Historic Environment Scotland. The authors would like to thank the building owners for providing access to the properties and archives and
J. Addison, A. Crone, A. Lewis, A. Mackechnie, K. Newland and F. Sutherland for their help and advice.

\section{REFERENCES}

Buildings at Risk Register 2015. Available from: $<$ http://www.buildingsatrisk.org.uk/advanced $>$. [23 November 2015].

Crone, A. \& Mills, C. M. 2012. Timber in Scottish buildings, AD 1450 - AD 1800; A dendrochronological perspective. Proc Soc Antiq Scotland, 142, 329-369.

Cruz, H., Yeomans, D., Tsakanika, E., Macchioni, N., Jorissen, A., Touza, M., Mannucci, M., \& Lourenco, P. B., 2015. Guidelines for on-site assessment of historic timber structures. Int J Archit Herit, 9:3, 277-289.

Feio, A., \& Machado, J. S., in press. In situ assessment of timber structural members: combining information from visual strength grading and NDT/SDT methods - a review. Constr Build Mater.

Glendinning, M. \& Mackechnie, A. 2004. Scottish architecture. London: Thames \& Hudson.

Gómez Sánchez, I. 2006. Las estructuras de madera en los Tratados de Arquitectura (1500-1810). Madrid: AITIM.

González-Longo, C., 2012. James Smith \& Rome. Arch Herit. XXIII, 75-96.

González-Longo, C. \& Theodossopoulos, D., 2012. From Master Mason to Architect: James Smith's Construction Techniques at the End of $17 \mathrm{C}$ in Scotland. In R. Carvais et al (eds.), Proc. 4th Intern Constr History Congress. Paris: Picard.

Hanke, T. 2006. The Development of Roof Carpentry in South East Scotland Until 1647. MSc diss, Edinburgh University.

Historic Scotland 2015. Available from: <http://www.historicscotland.gov.uk/>. [23 November 2015].

Kloiber, M., Drdacky, M., Machado, J., S., Piazza, M., \& Yamaguchi, N. In press. Prediction of mechanical properties by means of semi-destructive methods: a review. Constr Build Mater.

Macchioni, N., 2010. Species Identification. In-situ assessment of structural timber, in Kasal B. \& Tannert T. (eds.), RILEM State of the art reports, Springer, 59-66.

Newland, K. C. 2010. The Acquisition and Use of Norwegian Timber in Seventeenth Century Scotland, with reference to the principal building works of James Baine, his Majesty's Master Wright. PhD thesis, University of Dundee.

Ridout, B. 1999. Timber decay in buildings: the conservation approach to treatment. Taylor \& Francis.

Ruddock, T. 1995. Repair of two important early Scottish roof structures. Proc Instit Civil Eng, 110, 296-307.

Serafini, A. \& Gonzalez Longo, C. 2015. The design and construction techniques of eighteenth century timber roofs in Scotland: Glasgow Trades Hall and Tweeddale House in Edinburgh. In Donald Friedman et al (eds.), Proc. $5^{\text {th }}$ Intern. Constr. History Congress, 3-7 June 2015, Chicago.

Stell, G. \& Baillie, M. 1993. The Great Hall and Roof of Darnaway Castle, Moray. Moray: Province and People, Edinburgh, 163-179.

Tampone, G., 2007. From Material to Structure - Mechanical Behaviour and Failures of the Timber Structures. ICOMOS IWC XVI Intern Symp, Florence, Venice, Vicenza.

Thomson, A. 1991. The Scottish timber trade, 1680 to 1800. PhD thesis, University of St Andrews.

Royal Commission on the Ancient and Historical Monuments of Scotland 2015. Available from: $<$ https://canmore.org.uk/>. [23 November 2015].

Yeomans, D. T. 1992. The trussed roof: it's history and development. London: Scolar Press. 